\title{
People, Power, and the Coast: a Conceptual Framework for Understanding and Implementing Benefit Sharing
}

\author{
Rachel Wynberg ${ }^{1}$ and Maria Hauck ${ }^{1}$
}

\begin{abstract}
The concept of benefit sharing has seen growing adoption in recent years by a variety of sectors. However, its conceptual underpinnings, definitions, and framework remain poorly articulated and developed. We aim to help address this gap by presenting a new conceptual approach for enhancing understanding about benefit sharing and its implementation. We use the coast as a lens through which the analysis is framed because of the intricate governance challenges which coastal social-ecological systems present, the increasing development and exploitation pressures on these systems, and the growing need to improve understanding about the way in which greater equity and reduced inequalities could reduce conflicts, protect coastal ecosystems, and ensure greater social justice. Key elements of the framework include the range of actors involved, the natural resources they access and use, the interventions introduced to redistribute benefits, and the benefits and losses that result from these interventions. The framework underscores the importance of process in determining who gets what, as well as the wider institutional, political, social, and economic context. Power relations and imbalances underpin many of these elements and remain the central reason for benefits being distributed in the way that they are. The framework has relevance and application for coastal livelihoods, rural governance, and resource sustainability in a context in which community rights are increasingly undermined through land grabbing, unequal power relations, and externally driven development interventions.
\end{abstract}

Key Words: coastal communities; governance; inequality; power

\section{INTRODUCTION}

The concept of benefit sharing, meaning the division and distribution of monetary and nonmonetary benefits in a way that has equitable outcomes and is procedurally fair, has seen growing adoption in the development and conservation discourse in recent years. Its origins are likely rooted in the Convention on Biological Diversity (United Nations 1992) which, for the first time, introduced "access and benefit sharing" as a legal expression. This formulation arose from the unequal distribution of biodiversity throughout the world, the desire of biodiversity-poor but technology-rich industrialized countries to have continued access to these resources, and the determination of biodiversity-rich but technology-poor developing countries to benefit from the exploitation of their resources (Reid et al. 1993, Wynberg and Laird 2007). An agreement was reached requiring user countries to share benefits with provider countries, which in turn were required to facilitate access to their genetic resources (United Nations 1992, 2010).

Over and above genetic resources, notions of access and benefit sharing have progressively found expression in other sectors and disciplines. For example, over the past two decades, new peoplebased approaches towards conservation have embraced benefit sharing as a principle in the form, among others, of communitybased natural resource management (CBNRM), devolution of management responsibility, payment for ecosystem services, revenue sharing, comanagement, and recognition of the need for wildlife conservation and fisheries management to deliver concrete benefits to people to survive as a strategy (Fabricius et al. 2004, Kooiman et al. 2005, Schroeder 2008, Nelson 2010, Sommerville et al. 2010). In the tourism sector, benefit sharing is explored through a range of approaches that aim to address existing inequities among tourism stakeholders and the increasing losses experienced by host communities (Ashley et al. 2001, Scheyvens 2002, Saarinen et al. 2009).

Benefit sharing is also being explored as a policy incentive in the United Nations collaborative initiative on Reducing Emissions from Deforestation and forest Degradation (REDD) Programme in the climate change and conservation-finance discourse, which incorporates approaches such as participatory forest management, and forest concession revenue-sharing arrangements (Costenbader 2011). In the water sector, benefit sharing is increasingly used to describe the way in which the risks and benefits are shared among different users of a catchment, or those affected by dam construction (Mokorosi and van der Zaag 2007, Bazin et al. 2011). In this sector, benefit sharing is used as a practical policy tool to achieve greater social inclusiveness, improve local livelihoods, and reinforce social equity as an approach to promoting sustainability (Mokorosi and van der Zaag 2007, Bond and Mayers 2010, Bazin et al. 2011).

As awareness about the problems of inequality and unfair labor practices grows, another set of benefit-sharing interventions has emerged in the form of alternative trade movements, driven primarily by consumer concerns and a progressively vigilant civil society. One such initiative is "fair trade," born out of the objectives of putting people and their well-being before the pursuit of profit in trade and emphasizing the inequitable distribution of market power (Renard 2003, Nicholls and Opal 2005). Fair trade has its own spectrum of ideologies, but has rapidly become the consumer standard for social responsibility in the sourcing of agricultural commodities (Nicholls and Opal 2005).

What the literature reveals is that, despite increasing adoption of these benefit-sharing approaches, the concepts, definitions, and 
framework of benefit sharing remain poorly articulated and explored (Schroeder 2007). In some cases, the terminology is used simply to indicate attempts to introduce greater social responsibility, but remains embedded in a neoliberal discourse that is instrumentalist, reactive, or self-serving (Jenkins 2004, Merino and Valor 2011). In others, benefit sharing may be adopted as a development tool, but without an interrogation of the roots of the problem (Altman 2009). Other approaches may be more normative, signifying a new way of approaching natural resource management and spreading the costs and benefits of using and conserving ecosystems and their resources across actors (Schroeder 2008, Sommerville et al. 2010, Ha et al. 2012).

Although some recent attempts have been made to offer a definition for benefit sharing (Schroeder 2007), a typology of different benefit-sharing arrangements (Nkhata et al. 2012), or a political framework for understanding access to benefits (Ribot and Peluso 2003), the conceptual underpinnings of benefit sharing remain weakly developed. We aim to help address this gap by presenting a new conceptual approach for enhancing understanding about benefit sharing, thereby influencing implementation. We use the coast as a lens through which the analysis is framed because of the increasing development and exploitation pressures on coastal systems, and the growing need to improve understanding about the way in which greater equity and reduced inequalities could reduce conflicts, protect coastal ecosystems, and ensure greater social justice. The framework has relevance and application for coastal livelihoods, rural governance, and resource sustainability in a context in which community rights are increasingly undermined through land grabbing, unequal power relations, and externally driven development interventions. We believe benefit sharing can be used as an approach to address some of these pressing challenges.

Although we base our work on economic activities in coastal areas, we believe the overall framework may also be appropriate for other contexts. We ground our framework on a 3-yr project in southern Africa (2009-2011) that undertook detailed casestudy research in six sites: the communities of Josina Machel, Conguiana, and Gala in Mozambique, and Sokhulu, Mbonambi, and Mankosi in South Africa. All are marginalized or poor communities reliant on coastal resources, and most are involved in diverse initiatives by the state, community, nongovernmental organizations (NGOs) and/or the private sector that aim to redistribute benefits. Our unit of analysis was at the community level, and was focused on deepening understanding about community perspectives of benefits and losses arising from different initiatives. We conducted 514 household surveys, 44 focus groups, and $47 \mathrm{key}$ informant interviews, investigating the extent to which rural communities benefit from use of coastal resources, the approaches used to distribute benefits, and governance arrangements that enable or constrain more equitable benefit sharing. We explored a diversity of arrangements and investigated three sectors: fisheries, mining, and tourism. We also examined interactions of benefits and losses among sectors. We used both qualitative and quantitative methods in our analysis, preferring a mixed-method approach to reveal benefit-sharing perceptions, practices, and trends at the community level in particular. The empirical work informing the conceptual framework is presented in Wynberg and Hauck (2014).

\section{COASTAL AREAS AS A LENS ON BENEFIT SHARING}

Coastal ecosystems, which we define as coastal lands, areas where freshwater and saltwater mix, and near-shore marine areas (Agardy et al. 2005), are vital for communities in developing countries, many of whom live in abject poverty. Not only do they provide direct benefits such as jobs, food, fuel wood, medicines, building materials, and ornamental products (Wilson et al. 2004, Agardy et al. 2005, Brown et al. 2008) but they also deliver a host of sometimes intangible social benefits such as greater food security and social cohesion, as well as the higher level of wellbeing ascribed to living along the coast (Wilson et al. 2004).

The coastal zone also performs a multitude of so-called ecosystem services, helping to attenuate floods, giving protection from storm surges, assisting with waste assimilation, offering habitats for a diverse array of organisms and providing amenity services such as tourism and recreation (Costanza et al. 1997, Agardy et al. 2005, Brown et al. 2008, The Economics of Ecosystems and Biodiversity 2010). These services, many of which remain outside of the market system, are estimated to contribute up to U.S. $\$ 10.6$ trillion a year - equating to $43 \%$ of the estimated total value of global ecosystem services (Costanza et al. 1997). Although the specific figures are debatable, it cannot be denied that the coastal zone, although it covers just $8 \%$ of the world's surface, makes vital contributions to human well-being and ecological functioning (Agardy et al. 2005).

Coastal ecosystems rival tropical rainforests in their productivity (Barbier 1994) and their resources underpin the profitability of a wide range of economic sectors such as mining, fisheries, and tourism, which supply expanding global consumer markets. For example, the value of the worldwide industry in titanium dioxide extracted from heavy mineral sands on coastal dunes has been estimated at U.S.\$7 billion (Tyler and Minnitt 2004); capture fisheries in coastal waters alone generate some U.S.\$34 billion per annum (Agardy et al. 2005); and tourism linked to the scenic beauty and recreational opportunities of coastal areas has been estimated at nearly U.S.\$30 billion for nature-based and dive tourism in coral reefs alone (Cesar et al. 2003).

These activities provide significant opportunities for economic and income growth, reflected in the fact that more than 2 billion people live within $100 \mathrm{~km}$ of a coastline (Agardy et al. 2005). Moreover, coastal areas generate $61 \%$ of the world's total gross national product (GNP), and the greatest concentration of wealth, as measured by GNP, also occurs in these areas (Agardy et al. 2005). However, at the same time, industrial and other economic activities are often the chief culprits of overexploitation, habitat degradation, and pollution (Agardy et al. 2005). Moreover, as Brown et al. (2008:7) describe it, the poor are often the victims of resource degradation, living among the "effluents of industry."

Global patterns indicate growing levels of economic inequality between custodians of coastal resources and those exploiting them (Agardy et al. 2005), as well as an increasing incidence of absolute poverty among coastal communities that lack even the minimal income required for basic needs such as food, shelter, healthcare, and clothing (Campbell et al. 2006, Brown et al. 2008). Moreover, many coastal communities remain politically and economically marginalized, which leads to conflict over access to the resources and benefits of coastal areas (Newton et al. 2007, 
Brown et al. 2008). This has been exacerbated by the increased vulnerability of such communities to the impacts of ecosystem degradation and environmental change (Brown et al. 2008), and by the distorted way in which coastal ecosystem services are distributed and degraded, the costs of which are borne disproportionately by the world's poor (Newton et al. 2007, Srinivasan et al. 2008, Turner and Fisher 2008).

Increasingly, therefore, coastal areas are sites of contestation by different stakeholders. Technological advances and increased consumer demand for seafood, for example, have pushed many coastal resources beyond sustainable limits, leading to increased conflicts between small-scale and industrial fisheries (Ghee and Valencia 1990, Graham 2009), while the human health effects of living in degraded or polluted ecosystems often afflict the poor most heavily (Creel 2003, Agardy et al. 2005, Newton et al. 2007, Srinivasan et al. 2008).

Resolving these issues means approaching inequality, poverty, and ecological sustainability as part of an inextricably connected triad. This is not easy. Like many other landscapes, coastal areas are complex social-ecological systems that form part of a composite, dynamic, and diverse mosaic of landforms, human uses, weather phenomena and ecosystems (Holling 2001, Berkes et al. 2003). Moreover, the coast epitomizes the way in which different sectors interact in a common space, often pursuing similar resources, with interlinking implications for benefit distribution. Coastal systems have the added complexity of being the interface between land and sea and thus present a suite of intricate governance challenges. As Jentoft and Chuenpagdee (2009:553) remark, fisheries and coastal governance are a "wicked problem confronting governors with a daunting task where no simple solution may be found and where no single management tool will suffice." Adding justice and equity to this mix is almost guaranteed to present intractable challenges.

\section{BENEFITS, LOSSES, AND BUSINESS AS USUAL}

What is benefit sharing and how does it differ from what we call "business as usual"? Perhaps it is easier to understand the concept once one has grasped what it is not. As is now well recognized, economic growth has not only ignored the finite nature of the natural resource base and the planet's limited ability to absorb pollution and waste, but has also encouraged maximized consumption of natural resources (Daly and Cobb 1989, Korten 1995, Bakan 2002). Capitalism is driven by the individual maximization of company profit, but the famous invisible hand of the market has not delivered the requisite public welfare benefits (Daly and Cobb 1989, Chomsky 1999, Newell 2010). The consequences of this approach are well known: runaway climate change, accelerated biodiversity loss and deforestation, a decline in well-being for billions of people, and a planet that many describe as being at a tipping point of irreversible change (World Health Organization 2005, Rockström et al. 2009, Biermann et al. 2012, Organisation for Economic Co-operation and Development 2012). The underlying stimulus of this is consumption, which has spiraled in response to ever-increasing consumerism among more and more people, and the rapid growth of economies such as China, India, and Brazil. This, then, is the "business as usual" scenario, depicted in Fig. 1, where the losses associated with acquiring economic benefits - including habitat destruction, ecological degradation and pollution, social conflict, economic marginalization, and reduced access to resources - may well exceed any benefits secured by firms, individuals, governments, or communities. We use the term "losses" as opposed to "costs" here in a deliberate attempt to embrace a wider social meaning that recognizes the multiple dimensions of human well-being and equity and moves away from the economic language of cost-benefit analysis (Wegner and Pascual 2011).

Mining, for instance, creates jobs, generates significant tax revenues for governments, and may produce phenomenal profits for companies, but these benefits are typically based on shortterm economic gain, with longer-term losses for communities and the environment that can be devastating (e.g., Kapelus 2002, Jenkins 2004, Altman 2009). In coastal areas, mining activities can have wide-ranging negative impacts on indigenous forests, dune dynamics, and the hydrology and physical topography of rivers, estuaries, and beaches (Sibaud 2012). Not only do these activities lead to habitat fragmentation, but they may also reduce soil fertility and increase pollution (e.g. Lubke et al. 1996, Ramirez et al. 2005). At the same time, mining activities catalyze substantial social disruption, change and, in some cases, conflict; they diminish access to the natural resources upon which people depend; and may also cause significant health impacts (Boele et al. 2001, Madihlaba 2002, Twerefou 2009).

In the communities of Sokhulu and Mbonambi adjacent to Richards Bay on the KwaZulu-Natal coast of South Africa, two of the research sites upon which we base our analyses, titanium mining has caused the wholesale destruction of almost all coastal indigenous forest upon which communities rely for medicines and food, led to the flooding and pollution of subsistence agricultural lands, and fundamentally changed the hydrology of the region (Vivier and Cyrus 1999, Vivier 2010, Mbatha and Wynberg 2014). Mining contributes $19 \%$ and $30 \%$ respectively of household monthly incomes in Sokhulu and Mbonambi; yet, as many as $40 \%$ and $71 \%$ of these respective households indicated that mining had negatively impacted their lives (Mbatha and Wynberg 2014). Fishers, farmers, and even mining employees reported that the benefits that they received from mining were outweighed by the ecological and social losses they experienced. Such scenarios play themselves out again and again elsewhere in the world: the environmental and social devastation of oil pipelines in Nigeria and elsewhere (Boele et al. 2001, O'Rourke and Connolly 2003, Sibaud 2012); the forced removal of communities in eastern Zimbabwe to make way for diamond mining (Katsaura 2010); and the debilitating impacts of acid-mine drainage on the health of inhabitants of the Witwatersrand (Fig 2011, Gauteng Department of Agriculture and Rural Development 2012) to name but a few examples.

Similarly, there are challenges with securing benefits for smallscale fishers. Some $90 \%$ of the world's fishers operate on a small scale, with a major component harvesting coastal resources and residing in developing countries (Food and Agriculture Organization 2005). Approximately one billion people rely on fish as a major source of animal protein (Ziegler 2004). However, despite the importance of these small-scale fisheries in providing food security and livelihoods in coastal communities, they are largely marginalized throughout the world (Berkes et al. 2001). This is particularly evident in fisheries management policies that favor the capitalist interests of large-scale industrial fisheries over 
Fig. 1. "Business as usual" and benefit-sharing interventions in the context of activities pursued by different economic sectors.

\section{BUSINESS AS USUAL}

\section{BENEFIT-SHARING INTERVENTIONS}

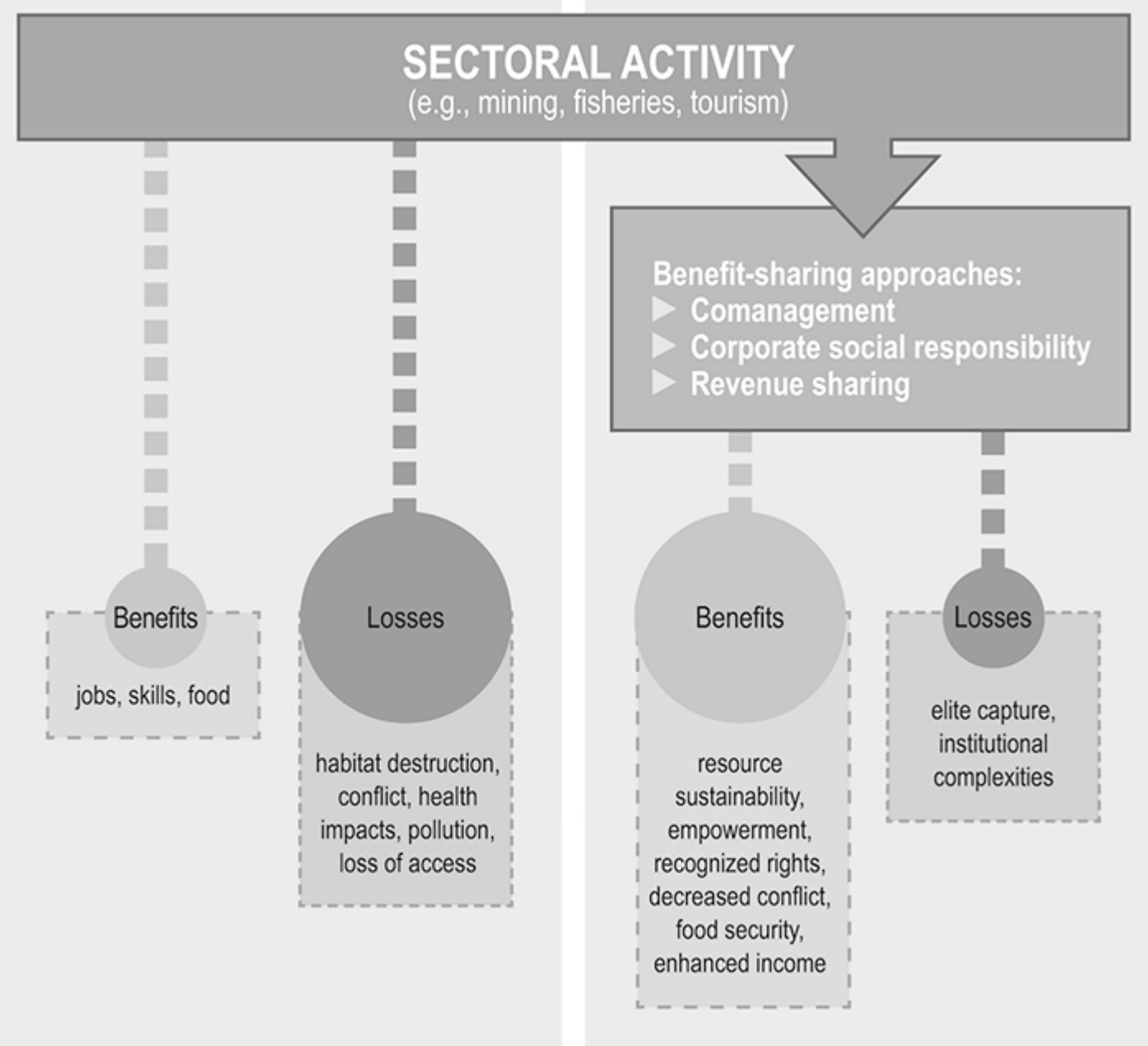

small-scale traditional ones (Ghee and Valencia 1990, de Graaf et al. 2003, Crosoer et al. 2006). In South Africa, for example, industrial fisheries were promoted for economic growth from the mid-1900s alongside flourishing recreational fisheries; yet, traditional small-scale fisheries in the case study communities of Sokhulu, Mbonambi, and Mankosi were considered illegal prior to 1994 and fishers were often arrested and fined. This resulted in a loss of access to food, perceived injustices over traditional rights and significant conflict, sometimes violent, between the fishers and the authorities (Hauck et al 2014).

Ironically, threats have also emerged from the conservation sector: conservation objectives are increasingly being favored over the social, cultural, and economic needs and rights of fishers and coastal communities (Pomeroy et al. 2007, Ruddle and Hickey 2008). International pressure to expand marine protected areas, for example, highlights a growing concern about the negative consequences of these conservation measures for communities, with fishers often dispossessed of their rights to access and use coastal resources and marine areas (Charles 2001, Christie 2004, Ruddle and Hickey 2008, Sowman et al. 2011). Not only does this affect fishers' abilities to secure food and income, it also often leads to social conflict, the erosion of cultural attachment to "place," ecological degradation from resource over-exploitation, and sometimes violent clashes between stakeholder groups (Charles and Wilson 2009, Sowman et al. 2011). In the Sokhulu case study, for example, although recreational fishing was still permitted, the promulgation of the adjacent Mapelane Nature Reserve in 1984 prohibited subsistence harvesting of coastal resources and, thus, access to food (Hauck et al. 2014). In Mozambique, fishers in the community of Josina Machel feared conservation groups who planned to establish protected areas in historically important fishing grounds, with potentially dire consequences to local livelihoods (Pereira and Hauck 2014). 
Inequitable fisheries and conservation policies coupled with growing tourism in coastal areas, are thus progressively encroaching on the rights and benefits of small-scale fishers and exacerbating the losses felt by them.

A similar trend is evident for tourism, which is considered one of the fastest growing economic sectors in developing countries and is widely promoted as a powerful tool for poverty reduction and economic development (Scheyvens 2007). The potential of tourism to significantly benefit host communities has been recognized, particularly in terms of generating employment and income, improving infrastructure inside the community, and enhancing knowledge and skills (Spenceley 2008, Saarinen et al. 2009). Increasingly, however, the negative impacts associated with tourism are being acknowledged. As Mitchell and Faal (2008:4) state, "reduced access to resources and negative social and cultural impacts sometimes threaten to overshadow the benefits that a vibrant tourism industry can generate." In the coastal sector, for example, protected areas or large developments established to promote tourism and/or conservation have often, at the same time, marginalized local fisher groups and adjacent coastal communities by creating conflict and limiting access to the coast and its resources (Masalu 2000, Fabinyi 2008, Ruddle and Hickey 2008). In two of our case-study communities in Mozambique (Conguiana and Josina Machel) where conventional tourism has been implemented, one-third of all respondents were employed by tourism initiatives, yet $69 \%$ and $76 \%$ respectively stated that they were negatively affected by tourism given restricted access to land and resources, environmental degradation, and social conflict (Pereira and Hauck 2014). Therefore, losses to communities can be significant if tourism developments take little or no account of the economic, social, and cultural well-being of local communities, the protection of the natural environment, and/or the inclusion of communities in decision making (Mitchell and Ashley 2010).

\section{THE SPECTRUM OF BENEFIT-SHARING INTERVENTIONS}

As understanding grows of these interlinkages between the benefits generated and the losses incurred in the process, new approaches are emerging that urge more equitable solutions and represent a move away from business as usual. Questions are being asked about the ultimate beneficiaries of resource use, especially in light of an ever-increasing gap between rich and poor, and the extent to which benefit distribution is fair and equitable. Some governments, companies, and development agencies are introducing new ways of working with communities, and are intervening in interesting and innovative ways to reduce inequality and ecological degradation and to promote improved benefits for the common good, with particular attention to poorer communities negatively affected by economic activities.

These so-called "benefit-sharing interventions," illustrated on the right side of Fig. 1, are described as the social processes or institutions through which people gain access to and control over resources and through which benefits are distributed (Ribot and Peluso 2003). They typically have the objective of redistributing benefits to different actors, and involve a decision-making process to determine who gets what. They incorporate a range of different approaches for achieving these goals, such as CBNRM, comanagement, corporate social responsibility, fair trade and certification, revenue sharing, payment for ecosystem services, or pro-poor tourism, each having varied outcomes and ideological bases. They also use certain tools to distribute benefits, such as permits, community levies, and equity in shares.

These approaches vary substantially depending on the global or local nature of the arrangement, the sector and actors involved, and the specific nature and history of the case in question. They also differ in their objectives, ideologies, and the extent to which they achieve equity. The diversity of these arrangements suggests that benefit-sharing interventions can best be described as a spectrum of approaches that have evolved to address a complex and often divergent set of redistribution objectives. Table 1 depicts this spectrum, summarizing the different types of interventions, their objectives and outcomes, their context, the natural resources used, the actors involved, the institutions and processes used to realize their objectives, and the power dynamics that often emerge. These factors are also the key components that we believe to be critical to understanding and analyzing benefit sharing and its effectiveness. Figure 2, which is discussed below, illustrates interactions among these components.

Community-based natural resource management, for example, arose out of a desire "to rectify the human costs associated with coercive conservation, [seeking] to return the stewardship of biodiversity and natural resources to local communities through participation, empowerment and decentralization" (Dressler et al. 2010:5). Many of the underlying principles of CBNRM have also been applied in cooperative or comanagement arrangements that often emerge as a result of concerns about resource management. The emphasis has been on sharing rights and responsibilities among governments, resource users, and other stakeholders to achieve sustainable and equitable resource governance (Pinkerton 1989, Borrini-Feyerabend et al. 2000, Carlsson and Berkes 2005, Roe et al. 2009).

In the small-scale fisheries arena, such approaches have been implemented to promote the equitable distribution of rights for coastal resources, reduce conflicts, enhance food security, and empower fishers and communities to engage actively in coastal governance (Berkes et al. 2001, Wilson et al. 2003, Hauck and Sowman 2005, Pomeroy and Rivera-Guieb 2006). With benefit sharing operationalized through decentralized committee structures, permits, capacity development, and revenue sharing, CBNRM and comanagement have in common a focus on strong institutions and participatory decision making, emphasizing legitimate, accountable, and fair governance arrangements (Jones and Murphree 2004, Larson and Ribot 2004, Carlsson and Berkes 2005). In our research, all six case-study sites had fisheries committees in place to engage at varying degrees with government. These were particularly instrumental in formalizing access to marine resources, which was considered meaningful to fishers for recognizing traditional rights, minimizing conflict in most cases, and providing a platform for engaging fishers in decision making. However, despite the introduction of fishing permits in communities in South Africa, between $37 \%$ and $86 \%$ of fishers remained without permits. This is perceived as an injustice when it is compared with the access given to recreational and commercial sectors (Hauck et al. 2014).

Revenue sharing has been promoted widely as a benefit-sharing approach in the tourism and conservation sectors, 
Ecology and Society 19(1): 27

Table 1. Examples of benefit-sharing approaches.

\begin{tabular}{|c|c|c|c|c|c|c|c|c|}
\hline $\begin{array}{l}\text { Benefit- } \\
\text { sharing } \\
\text { approach }\end{array}$ & $\begin{array}{l}\text { Natu- } \\
\text { ral } \\
\text { resou- } \\
\text { rces }\end{array}$ & Context & Actors & $\begin{array}{l}\text { Underpinning } \\
\text { objective }\end{array}$ & $\begin{array}{l}\text { Benefit-sharing } \\
\text { intervention }\end{array}$ & Process & Power & $\begin{array}{l}\text { Outcomes } \\
\text { (benefits/losses) }\end{array}$ \\
\hline $\begin{array}{l}\text { Community- } \\
\text { Based } \\
\text { Natural } \\
\text { Resource } \\
\text { Management } \\
\text { (CBNRM) }\end{array}$ & $\begin{array}{l}\text { wildl- } \\
\text { ife, } \\
\text { forest } \\
\text { prod- } \\
\text { ucts }\end{array}$ & $\begin{array}{l}\text { Political } \\
\text { context of } \\
\text { decentrali- } \\
\text { zation, } \\
\text { security of } \\
\text { tenure, } \\
\text { and } \\
\text { poverty } \\
\text { alleviation } \\
\text { linked to } \\
\text { conservation } \\
\text { movements. }\end{array}$ & $\begin{array}{l}\text { Different } \\
\text { levels of } \\
\text { government, } \\
\text { NGOs, } \\
\text { private } \\
\text { sector, and } \\
\text { communit- } \\
\text { ies. }\end{array}$ & $\begin{array}{l}\text { Sustainable } \\
\text { livelihoods, } \\
\text { social } \\
\text { justice, and } \\
\text { resource } \\
\text { sustainability. }\end{array}$ & $\begin{array}{l}\text { Decentralized } \\
\text { institutions set up to } \\
\text { allocate rights (i.e., } \\
\text { permits) to access, } \\
\text { use, and trade natural } \\
\text { resources, coupled } \\
\text { with revenue sharing } \\
\text { and broader support } \\
\text { to local communities } \\
\text { and livelihoods. }\end{array}$ & $\begin{array}{l}\text { Devolution and } \\
\text { participatory } \\
\text { decision making, } \\
\text { although this has } \\
\text { taken different } \\
\text { forms. }\end{array}$ & $\begin{array}{l}\text { Power imbalances } \\
\text { exist between and } \\
\text { within the different } \\
\text { actors, with the } \\
\text { intention of } \\
\text { transferring } \\
\text { greater power to } \\
\text { community } \\
\text { structures. } \\
\text { However, if } \\
\text { devolution is } \\
\text { weak, then power } \\
\text { continues to sit } \\
\text { with the state or } \\
\text { private sector. }\end{array}$ & $\begin{array}{l}\text { Benefits to communities can } \\
\text { be significant in terms of } \\
\text { securing access to land and } \\
\text { resources, enhancing } \\
\text { income, diversifying } \\
\text { livelihood opportunities, } \\
\text { capacitating local } \\
\text { institutions, building } \\
\text { empowerment, and reducing } \\
\text { overexploitation of } \\
\text { resources. } \\
\text { However, if devolution is } \\
\text { weak, if participatory } \\
\text { decision making is absent, } \\
\text { or if there are challenges } \\
\text { with implementation, losses } \\
\text { can lead to greater } \\
\text { centralization of use and } \\
\text { control of resources, } \\
\text { enhanced conflict between } \\
\text { actors, and elite capture of } \\
\text { benefits. }\end{array}$ \\
\hline $\begin{array}{l}\text { Cooperative } \\
\text { management } \\
\text { (comanagem- } \\
\text { ent) }\end{array}$ & $\begin{array}{l}\text { fishe- } \\
\text { ries }\end{array}$ & $\begin{array}{l}\text { Resource } \\
\text { overexplo- } \\
\text { itation and } \\
\text { conflict, } \\
\text { coupled } \\
\text { with } \\
\text { donor- } \\
\text { driven } \\
\text { agendas } \\
\text { and } \\
\text { policies } \\
\text { and laws } \\
\text { that favor } \\
\text { participation } \\
\text { and } \\
\text { decentrali- } \\
\text { zation. }\end{array}$ & $\begin{array}{l}\text { Largely } \\
\text { government } \\
\text { authorities } \\
\text { and } \\
\text { communities } \\
\text { but there } \\
\text { may be } \\
\text { other } \\
\text { actors } \\
\text { such as } \\
\text { NGOs and } \\
\text { scientists. }\end{array}$ & $\begin{array}{l}\text { Resource } \\
\text { sustainability } \\
\text { linked to } \\
\text { sustainable } \\
\text { livelihoods. }\end{array}$ & $\begin{array}{l}\text { Comanagement } \\
\text { committees set up to } \\
\text { facilitate joint } \\
\text { decision making on } \\
\text { resource management } \\
\text { and sometimes } \\
\text { livelihood support. }\end{array}$ & $\begin{array}{l}\text { Spectrum of } \\
\text { cooperative } \\
\text { decision making } \\
\text { with the intention } \\
\text { of sharing rights } \\
\text { and } \\
\text { responsibilities } \\
\text { between actors. }\end{array}$ & $\begin{array}{l}\text { Move from central } \\
\text { power to shared } \\
\text { power, but } \\
\text { imbalances remain } \\
\text { (power rests with } \\
\text { the state) when } \\
\text { decentralization is } \\
\text { weak. }\end{array}$ & $\begin{array}{l}\text { Benefits accrue to all actors } \\
\text { in the form of resource } \\
\text { sustainability and reduced } \\
\text { conflict. In addition, } \\
\text { communities often benefit } \\
\text { through greater or more } \\
\text { secure access to resources, } \\
\text { enhanced income or food, } \\
\text { capacity and skills } \\
\text { development, strengthening } \\
\text { of local-level institutions } \\
\text { and, in some cases, new } \\
\text { livelihood opportunities. } \\
\text { However, if devolution is } \\
\text { weak and there are } \\
\text { challenges with } \\
\text { implementation, losses can } \\
\text { lead to greater centralization } \\
\text { of use and control of } \\
\text { resources, enhanced conflict } \\
\text { between actors, and elite } \\
\text { capture of benefits. }\end{array}$ \\
\hline $\begin{array}{l}\text { Revenue } \\
\text { sharing }\end{array}$ & $\begin{array}{l}\text { wildl- } \\
\text { ife, } \\
\text { land, } \\
\text { forests, } \\
\text { plants }\end{array}$ & $\begin{array}{l}\text { Conflict, } \\
\text { as well as } \\
\text { policies } \\
\text { and laws } \\
\text { that } \\
\text { promote } \\
\text { poverty } \\
\text { alleviation } \\
\text { and } \\
\text { economic } \\
\text { developm- } \\
\text { ent. }\end{array}$ & $\begin{array}{l}\text { Governm- } \\
\text { ent, } \\
\text { communit- } \\
\text { ies, NGOs, } \\
\text { and the } \\
\text { private } \\
\text { sector. }\end{array}$ & $\begin{array}{l}\text { Reducing } \\
\text { conflict, } \\
\text { improving } \\
\text { the public } \\
\text { image and } \\
\text { local } \\
\text { attitudes to } \\
\text { conservation } \\
\text { and } \\
\text { tourism, } \\
\text { and } \\
\text { promoting } \\
\text { community } \\
\text { development. }\end{array}$ & $\begin{array}{l}\text { Funds accumulated } \\
\text { through fees, permits, } \\
\text { and/or taxes from } \\
\text { protected areas or } \\
\text { tourism } \\
\text { establishments are } \\
\text { allocated to local } \\
\text { communities. }\end{array}$ & $\begin{array}{l}\text { Community } \\
\text { institutions are set } \\
\text { up to receive and } \\
\text { distribute funds } \\
\text { through } \\
\text { participatory } \\
\text { decision making. }\end{array}$ & $\begin{array}{l}\text { Power rests with } \\
\text { the state in terms } \\
\text { of percentages } \\
\text { allocated to } \\
\text { communities but } \\
\text { the community } \\
\text { may decide how to } \\
\text { allocate the funds. }\end{array}$ & $\begin{array}{l}\text { Benefits include reduced } \\
\text { conflict and increased } \\
\text { community support for } \\
\text { protected areas, in addition } \\
\text { to enhanced income, } \\
\text { infrastructure development, } \\
\text { and livelihood support for } \\
\text { local communities. } \\
\text { However, losses can be } \\
\text { significant in terms of } \\
\text { minimal compensation for } \\
\text { loss of land and access to } \\
\text { resources. In addition, } \\
\text { conflict can be exacerbated } \\
\text { within communities along } \\
\text { with the elite capture of } \\
\text { benefits. }\end{array}$ \\
\hline
\end{tabular}




\begin{tabular}{|c|c|c|c|c|c|c|c|c|}
\hline $\begin{array}{l}\text { Corporate } \\
\text { Social } \\
\text { Responsibility } \\
\text { (CSR) }\end{array}$ & $\begin{array}{l}\text { mine- } \\
\text { rals }\end{array}$ & $\begin{array}{l}\text { Government } \\
\text { regulation } \\
\text { and policy, } \\
\text { shareholder } \\
\text { demand, } \\
\text { consumer } \\
\text { and public } \\
\text { pressure, } \\
\text { community } \\
\text { conflict, } \\
\text { and } \\
\text { market } \\
\text { competition. }\end{array}$ & $\begin{array}{l}\text { Driven by } \\
\text { the private } \\
\text { sector but } \\
\text { often also } \\
\text { involves } \\
\text { the state, } \\
\text { NGOs, } \\
\text { and } \\
\text { communit- } \\
\text { ies. }\end{array}$ & $\begin{array}{l}\text { Social } \\
\text { development } \\
\text { and } \\
\text { environmental } \\
\text { protection } \\
\text { while } \\
\text { maintaining } \\
\text { profits. }\end{array}$ & $\begin{array}{l}\text { Includes investments } \\
\text { in social development } \\
\text { and infrastructure (e. } \\
\text { g., roads, education, } \\
\text { health), local } \\
\text { procurement and } \\
\text { business development, } \\
\text { environmental } \\
\text { remediation, skills } \\
\text { training, and, in some } \\
\text { cases, community } \\
\text { shares and equity. }\end{array}$ & $\begin{array}{l}\text { A variety of } \\
\text { institutions are set } \\
\text { up to implement } \\
\text { CSR such as } \\
\text { community } \\
\text { development } \\
\text { committees, } \\
\text { partnership } \\
\text { arrangements, or } \\
\text { joint ventures. } \\
\text { Communities are } \\
\text { often identified in } \\
\text { a narrow way to } \\
\text { limit claims, } \\
\text { reduce costs, and } \\
\text { manage risks. }\end{array}$ & $\begin{array}{l}\text { Power relations are } \\
\text { typically highly } \\
\text { skewed. Power } \\
\text { usually resides } \\
\text { with the private } \\
\text { sector or local } \\
\text { elite. }\end{array}$ & $\begin{array}{l}\text { Benefits may include } \\
\text { improved infrastructure, } \\
\text { skills and knowledge } \\
\text { enhancement, job creation, } \\
\text { improved environmental } \\
\text { quality, increased income, } \\
\text { and, if implemented well, } \\
\text { improved community } \\
\text { relations and thus reduced } \\
\text { conflict. } \\
\text { CSR can also lead to } \\
\text { significant losses, including } \\
\text { increased intracommunity } \\
\text { conflict, state abdication of } \\
\text { its responsibilities, elite } \\
\text { capture of benefits, and } \\
\text { increased marginalization of } \\
\text { those who already lack a } \\
\text { voice. }\end{array}$ \\
\hline
\end{tabular}

characteristically driven by government, donors, NGOs, and the private sector. Funds are typically accumulated through levies, permits, and/or taxes that may be stipulated in law and then allocated to local communities. Although the objectives of revenue sharing may vary across initiatives, the approach is generally used to promote community development, reduce conflict, and improve the public image of conservation agencies or tourism operators (Mitchell and Ashley 2010, Ahebwa et al. 2012). Key activities relate to the establishment and empowerment of accountable community institutions, which are instrumental for receiving and distributing income fairly to the wider community (Tumusiime and Vedeld 2012, Archabald and Naughton-Treves 2001). Although there may be social and economic benefits to communities, these have often been regarded as inadequate compensation for significant loss of land or access to natural resources (Tumusiime and Vedeld 2012). In our casestudy community of Gala in Mozambique, revenue received from park fees of an adjacent protected area was seen as a benefit by all respondents in the community, bringing much-needed income (Pereira and Hauck 2014). Nonetheless, although there were clear benefits from revenue sharing, community members voiced their bitterness about historical loss of land and access to resources as a result of the protected area (Pereira and Hauck 2014).

One of the weaker approaches to benefit sharing that has emerged over the past $20 \mathrm{yrs}$ is that of corporate social responsibility (CSR), also referred to as corporate citizenship. As the name indicates, this is an approach driven predominantly by the private sector, but typically in response to government regulation, shareholder demand, or consumer or community pressure. Although not strictly a benefit-sharing intervention, CSR is about "balancing the diverse demands of communities and the imperative to protect the environment with the ever present need to make a profit" (Jenkins 2004:24) and "systematizing corporate contributions to development” (Merino and Valor 2011:165).

Specific interventions might include investments in social development and infrastructure projects, local procurement, environmental remediation, or community shares in private companies (Hamann 2003, Jenkins 2004). These are implemented through a range of institutions such as community-level development committees, partnership arrangements with NGOs or communities, or joint ventures. In contrast to the other approaches described above, the motivation of CSR is typically self-interest, in which power resides predominantly with the corporation itself, rather than with the stakeholders associated with the initiative (Jenkins 2004). Therefore, many dispute the claim that corporate contributions to communities have been positive overall (Frynas 2005, Merino and Valor 2011). This was also reinforced in our research, evidenced by a clear gap between the benefits that the mining company Richards Bay Minerals claims to give communities, and the perceived benefits secured by residents. Despite $19 \%$ and $30 \%$ of the employment in the communities of Sokhulu and Mbonambi coming from mining, $86 \%$ and $77 \%$ of households respectively believed that they did not benefit from the mining company's benefit-sharing interventions. Only $14 \%$ and $23 \%$ of respective households in Sokhulu and Mbonambi considered that they had benefited from CSR projects, with $4 \%$ and $13 \%$ satisfied with these benefits (Mbatha and Wynberg 2014). However, CSR is an evolving concept and, as Merino and Valor (2011) note, there are widely divergent understandings of its conceptual and ideological base. This is also reflected in the varied agendas that different companies pursue, from philanthropy and impact mitigation through to community investment and social partnerships between business and civil society (Hamann 2004).

\section{A CONCEPTUAL FRAMEWORK FOR BENEFIT SHARING}

Key elements of benefit sharing: natural resources, actors, benefit-sharing interventions, and outcomes

Conceptually, we understand benefit sharing to comprise a number of different but strongly interrelated components. These components have been identified through our research as crucial for developing, implementing, and assessing benefit-sharing interventions. Figure 2 presents key elements of this framework and illustrates a dynamic process by which interventions are introduced to distribute benefits in a more equitable manner to a range of actors who access and use natural resources in coastal areas. 
Fig. 2. Conceptual framework for benefit sharing in coastal resource use.

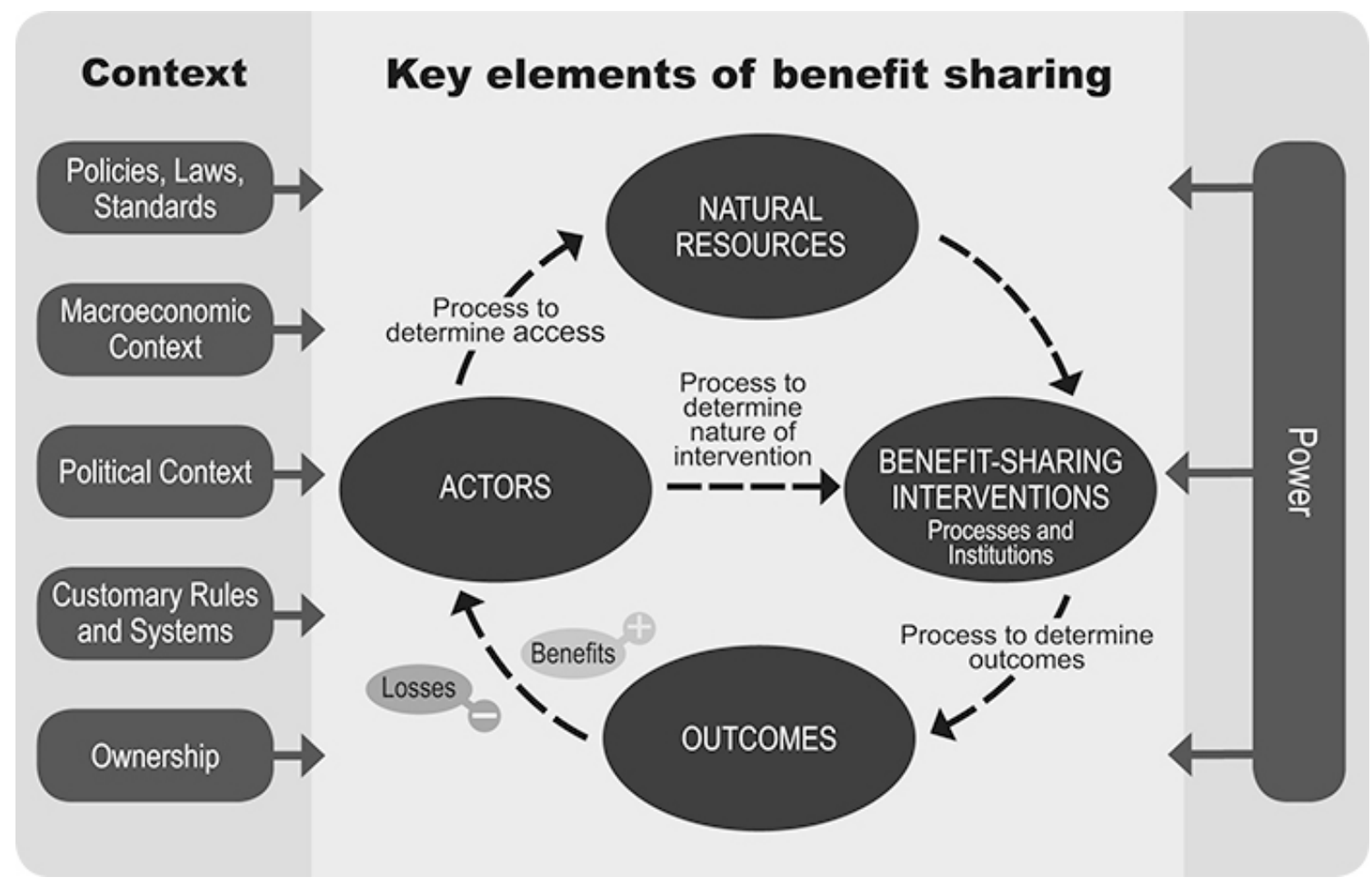

Such natural resources may include wildlife, fisheries, plants, minerals, forest products, or land, which are accessed by a suite of actors who often have divergent or even conflicting interests. These can include government departments, politicians, corporations and the business sector, conservation agencies, civil society organizations, and local communities, all of which operate at different levels, from global to local.

Interests may range from resource regulation, conservation, and human rights protection to gleaning tax revenues, generating profit, local economic development, and poverty alleviation. Such interests, along with the objectives of benefit-sharing interventions, are often at odds. Some actors, for example, may promote the conservation of natural resources at the expense of indigenous peoples' rights, whereas others may champion devolution and local tenure (Ruddle and Hickey 2008, Dressler et al. 2010). These conflicts, within and among groups of actors, are well recognized as an impediment to achieving more equitable and sustainable resource governance arrangements (Ribot and Peluso 2003, Roe et al. 2009, Dressler et al. 2010).

Benefit-sharing interventions are an important approach to mediating these conflicts, requiring careful and participatory design, building on existing or involving new processes and institutions, with each intervention individually crafted and customized to cater to a specific situation. The outcomes of these interventions will affect a range of actors, and, although they aim to enhance benefits overall, they can also cause significant losses, with negative social, economic, and ecological implications (Ashley and Roe 2002, Chuenpagdee et al. 2005, Altman 2009, van der Duim 2011).
A significant challenge is to develop methodologies that can accurately and fairly assess benefits and losses among different actors, including the trade-offs that may be required among them. In this regard, increased recognition is being given to the flaws of "monistic" methods of benefit sharing such as cost-benefit analysis or ecosystem service valuation, which often fail in their attempts to "objectively" quantify different values in complex social and ecological ecosystems that are inherently political, that have multifaceted power dynamics and plural forms of value articulation, and that are often governed by the distributional biases of markets (Spangenberg and Settele 2010, Wegner and Pascual 2011). A pluralist approach that could be further explored within the context of this conceptual framework is that of multistakeholder, multicriteria analysis that, for example, has been used as a decision support tool for integrated coastal zone management (Garmendia et al. 2010, Wegner and Pascual 2011).

\section{The importance of process}

Figure 2 also emphasizes the importance of process in determining who gains access to natural resources and, therefore, who benefits, as well as the centrality of process in shaping actor involvement in benefit-sharing interventions and their outcomes. Indeed, participatory processes and procedural fairness are critical to ensuring the effectiveness of benefit sharing, and securing a legitimate and equitable outcome (Hernes et al. 2005). Thus, the establishment of local-level institutions is integral to such processes, in which representative actors engage in joint decision making (Noble 2000, Pomeroy and Rivera-Guieb 2006). However, such processes, which need to adapt and evolve as needs and circumstances change, require time and resources, and it must be understood that a mismatch between the expectations and 
interests of different actors could jeopardize expected outcomes (Jones and Murphree 2004, Wynberg et al. 2009). Depending on the situation and capacities of actors, there may well be a vital role for a skilled facilitator or "honest broker" that is trusted by all actors.

\section{The context of benefit sharing}

The interventions that are developed to distribute benefits more equitably are typically located within a wider institutional, political, social, and economic framework and are consequently influenced by multiple interlaced factors. For example, policies, laws, and standards may in effect benefit certain actors more than others. Informal institutions, such as customary rules and systems, may conflict with formal laws and thus result in confusing systems of dual governance. Political objectives, for instance decentralization in post-colonial states, will have a significant impact on legal reform and foreign aid (Ashley and Roe 2002, Ruddle and Hickey 2008).

At the same time, the implementation of such laws and policies is likely to be hampered by other factors, such as the macroeconomic influences of neoliberal and capitalist economies (Dressler et al. 2010, Cunguara and Hanlon 2012). Market forces may also drive the establishment of certain benefit-sharing interventions, or may directly influence the value of a particular resource, and thus the behavior of certain actors. These wider influences, often driven by actors at international and national level, can have significant impacts at local level and may be juxtaposed with the realities and needs of marginalized communities (Ruddle and Hickey 2008, Nelson 2010). They will also interplay with property rights (Ostrom 1990), as well as with a range of mechanisms and structures governing resource use, such as social identity, social status, and social relations (Ribot and Peluso 2003).

\section{Power as a central determinant of benefit sharing}

Power relations constitute the common denominator underpinning many of these elements and remain the central reason for the way in which benefits are distributed. Power, according to Gaventa (2006), is tridimensional: it operates at different levels (international, national, and local) and within different spaces (closed, invited, and claimed), and it can be of different natures. For example, power may be visible, through observable decision making, but may also be more clandestine, if powerful people and institutions prevent alternative voices and viewpoints from getting a fair hearing (Gaventa 2006). Where "invisible" psychological and ideological boundaries are set, power may also be more insidious, perpetuating inequality and social justice (Gaventa 2006).

As Ribot and Peluso (2003:173) argue, the structural and relational mechanisms of access - to markets, capital, technology, knowledge, or authority - form "bundles of powers" that result in "complex social patterns of benefit distribution." They also result in some actors holding more power than others, and influencing particular courses of action to secure greater benefits, with local resource users most often the ones losing out (Binot et al. 2009, Nelson 2010). The value of the resources plays a central role in determining the interest of different actors. Indeed, whichever natural resource has the greater value tends to be the code that governs, with governments typically retaining highvalue resources to maintain power and control, and to shape benefits (Nelson 2010, Ahebwa et al. 2012).
Certain actors, including those at the local level, also have the power either to reinforce or to contradict equitable governance arrangements, including the ability to shape policy and law, and to maintain the monopolies of their position (Jones and Murphree 2004, Nelson 2010). This has obvious consequences for benefit sharing, leading to the elite capture of benefits and deepened inequalities (Murphree 2004, Binot et al. 2009, Nelson 2010). Such contests and power imbalances over resource rights and benefits are fundamental to our understanding of benefitsharing arrangements and outcomes.

\section{Designing, implementing, and analyzing benefit sharing}

Enhancing understanding about benefit sharing is important, but equally relevant is the question of how this knowledge can be practically applied, both in the coastal zone and across wider social-ecological systems, to reduce inequalities and enhance the governance and sustainable use of natural resources. Table 2 provides an indicative list of the kinds of questions that should be asked by those implementing benefit-sharing arrangements, to assess and analyze existing interventions and their impacts in communities. These questions could be asked by governments, NGOs, companies, or consultants, at various scales, and used together with Fig. 2, could provide a practical tool for the application of the framework.

The questions explored and analyzed in Wynberg and Hauck (2014), for example, describe how titanium mining along the KwaZulu Natal coast in South Africa is dictated to a large extent by the contextual issues of market demand, regulatory frameworks for environmental protection, equity and black economic empowerment, histories of dispossession and skewed land ownership, and the undemocratic traditional authorities that hold sway in the area. The high value of titanium suggests that the benefits of this natural resource will be strongly contested; indeed, the case is characterized by multiple actors that include the private sector (Richards Bay Minerals), national government, the local municipality, traditional authorities, and affected communities. Two benefit-sharing interventions have been introduced by Richards Bay Minerals: corporate social responsibility and black economic empowerment, along with a multiplicity of uncoordinated implementing institutions. In each case, their effectiveness has been hampered by inadequate processes to determine the nature of access and the nature of the intervention, including a lack of downward accountability and transparency, elite capture of benefits, and misuse of power. Power thus remains a highly significant factor impeding the ability of the broader community to benefit. Although traditional authorities are one of the central obstacles to more equitable benefit distribution, the company itself has also followed the route of expediency in the way in which it has exploited local institutional fragilities. The outcomes of these arrangements manifest in community perceptions that the economic benefits of mining are outweighed by the significant social, ecological, and economic losses they incur.

The questions presented in Table 2 could also be modified to help those who are in the process of developing benefit-sharing arrangements, to highlight key areas to consider when designing the intervention. Thus, careful use of these questions alongside the conceptual framework might help to guide actors towards more equitable and sustainable solutions for natural resource use and their governance. 
Table 2. Key questions to consider when developing, implementing, and analyzing benefit-sharing arrangements

\section{Natural resources}

What resources are currently being harvested?

What resources have historically been harvested?

What is the ecological or physical state of the resource?

What is the ecological state of the ecosystem in which the resource occurs?

What are the requirements for sustainable use?

What management systems are in place?

How does monitoring and assessment take place?

Are there any environmental "red flags" that need attention? (e.g., habitat destruction or degradation, pollution and waste, invasive species, climate change)

\section{Actors}

What people or groups are currently harvesting or using these natural resources?

What other livelihoods do people pursue?

Who is actively involved in decision making related to resource use?

Who is affected by resource use (positively and negatively)?

Have the people who use or manage natural resources changed over time? If so, why?

Who is actively involved in benefit-sharing arrangements?

What is the underlying interest or key objective driving each actor's involvement in the benefit-sharing arrangement?

Process to determine access

How is access to resource use determined?

What institutional structures are in place to determine access?

What actors participate in determining access?

Benefit-sharing interventions

What arrangements have been initiated to share benefits more equitably between actors?

Who initiated these benefit-sharing arrangements and why?

What institutions have been set up to implement these arrangements?

Process to determine nature of intervention

How were benefit-sharing arrangements identified and initiated?

What were the drivers that led to the establishment of the benefit-sharing arrangement?

How were the actors identified to participate in the benefit-sharing arrangement?

How was the process for identifying and implementing the benefit-sharing arrangement determined?

Outcomes

Who benefits from the benefit-sharing arrangement and how?

Who is negatively affected by the benefit-sharing arrangement and how?

Has the implementation of benefit-sharing interventions brought any problems? If so what?

Are outcomes considered fair by all the different actors involved or only some?

Are benefits distributed equitably?

Did benefits and losses change over time? If so, how?

Process to determine outcomes

What outcomes were intended through the benefit-sharing arrangement?

How were the outcomes determined, and by whom?

Was the process for determining outcomes considered fair by the different actors involved?

Context

What external factors have driven the initiation of benefit-sharing arrangements?

What external factors have influenced the outcomes that have resulted from these arrangements?

What external factors have influenced the range of actors involved?

Power

Are benefit-sharing institutions considered fairly represented by the different actors involved?

What are the existing power imbalances between the different actors that influence decision making and outcomes?

Do the different actors involved in benefit-sharing arrangements perceive power to be equally shared? Why or why not?

Has power shifted in any way as a result of the benefit-sharing arrangement? If so, how?

Table 3 takes this assessment process further by summarizing some of the enabling and constraining factors that may indicate a successful process and outcome. For example, robust institutions, trust, adaptive management, secure tenure, and wellfunctioning ecosystems are likely to indicate a favorable climate for benefit sharing. However, no matter how well intentioned the 
initiative, equitable benefit sharing may be impeded by other factors, including political interference and patronage, autocratic decision making, uncoordinated initiatives, elite capture of benefits, and degraded or scarce resources. Further research is needed to secure a deeper understanding of the interactions of these different factors, and of innovative approaches that can quantify, without oversimplifying, the different values that benefits and losses have for different actors.

Table 3. Factors that enable and hinder benefit sharing for coastal resources.

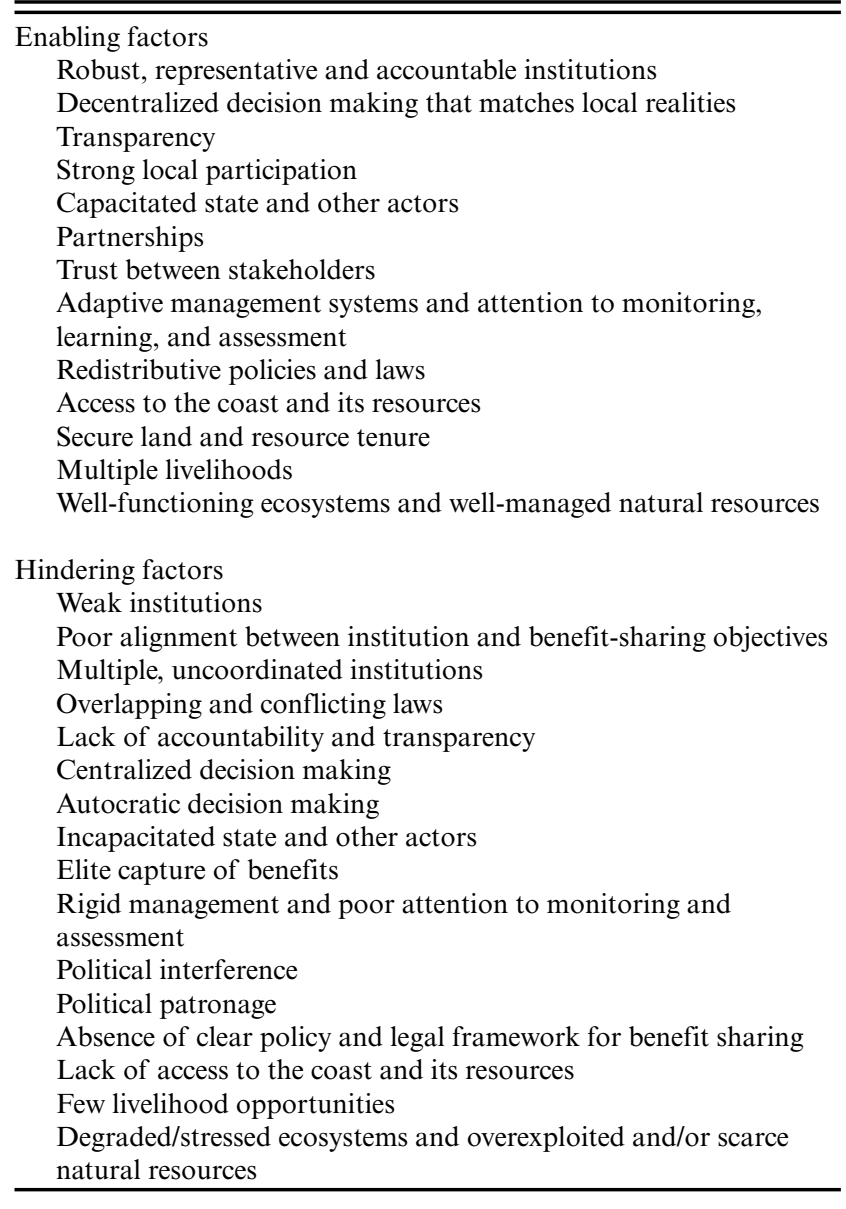

\section{CONCLUSION}

Inequities in coastal areas remain rife, the poor are getting poorer, and coastal resources are being exploited to unsustainable levels (Agardy et al. 2005). Through understanding economic and power imbalances among actors, and identifying strategies to distribute benefits arising from natural resource use more fairly, we may be better placed to address these problems and thus reduce poverty and improve the governance and sustainable use of natural resources. The conceptual framework presented here, along with the literature and empirical research upon which it draws, highlight the complexities involved in understanding and implementing benefit sharing of coastal resource use, where there are a range of actors, resources, institutional arrangements, and social, political, and economic influences. Although the task seems daunting, it is vital that we begin to interrogate and deepen understanding of the component parts of benefit sharing, as well as the wider institutional reforms required to promote social justice, equity, and empowerment. Doing so across and within sectors, through conscious and deliberate use of the terminology and concepts, provides a first step towards shifting both policy and praxis.

Responses to this article can be read online at: http://www.ecologyandsociety.org/issues/responses. $\mathrm{php} / 6250$

\begin{abstract}
Acknowledgments:
Our warm thanks to Philile Mbatha, Mayra Pereira, Serge Raemaekers, and Merle Sowman who participated in lively and stimulating debates as the conceptual framework unfolded. We gratefully acknowledge the Western Indian Ocean Marine Science Association and the Swedish International Development Agency for their generous support of this project. Paul Wise, Paula Wood, and Jaci van Niekerk are thanked for assistance with editing and illustrations. The comments of two anonymous reviewers greatly improved the manuscript.
\end{abstract}

\section{LITERATURE CITED}

Agardy, T., J. Alder, P. Dayton, S. Curran, A. Kitchingman, M. Wilson, A. Catenazzi, J. Restrepo, C. Birkeland, S. Blaber, S. Saifullah, B. Branch, D. Boersma, S. Nixon, P. Dugan, N. Davidson, and C. Vorosmarty. 2005. Coastal systems. Pages 513 549 in Millenium ecosystem assessment: ecosystems and human well-being. Volume 1: current state and trends: analytical approaches for assessing ecosystems and human well-being. Island Press, Washington, D.C., USA.

Ahebwa, W. M., R. van der Duim, and C. Sandbrook. 2012. Tourism revenue sharing policy at Bwindi Impenetrable National Park, Uganda: a policy arrangements approach. Journal of Sustainable Tourism 20(3):377-394. http://dx.doi. org/10.1080/09669582.2011.622768

Altman, J. 2009. Benefit sharing is no solution to development. Pages 89-126 in R. Wynberg, R. Chennells, and D. Schroeder, editors. Indigenous peoples, consent and benefit-sharing. Lessons from the San-Hoodia case. Springer, Berlin, Germany. http://dx. doi.org/10.1007/978-90-481-3123-5 15

Archabald, K., and L. Naughton-Treves. 2001. Tourism revenuesharing around national parks in western Uganda: early efforts to identify and reward local communities. Environmental Conservation 28:135-149. http://dx.doi.org/10.1017/S0376892901000145

Ashley, C., and D. Roe. 2002. Making tourism work for the poor: strategies and challenges in southern Africa. Development Southern Africa 19(1):61-82. http://dx.doi.org/10.1080/0376835$\underline{0220123855}$

Ashley, C., D. Roe, and H. Goodwin. 2001. Pro-poor tourism strategies: making tourism work for the poor: a review of experience. Overseas Development Institute, London, UK. 
Bakan, J. 2002. The corporation: the pathological pursuit of profit and power. Penguin, Toronto, Ontario, Canada.

Barbier, E. B. 1994. Valuing environmental functions: tropical wetlands. Land Economics 70(2):155-173. http://dx.doi. org/10.2307/3146319

Bazin, F., J. Skinner, and J. Koundouno, editors. 2011. Sharing the water, sharing the benefits: lessons from six large dams in West Africa. International Institute for Environment and Development, London, UK.

Berkes, F., R. Mahon, P. McConney, R. Pollnac, and R. Pomeroy. 2001. Managing small-scale fisheries: alternative directions and methods. International Development Research Centre, Ottawa, Ontario, Canada.

Berkes, F., J. Colding, and C. Folke. 2003. Navigating socialecological systems: building resilience for complexity and change. Cambridge University Press, Cambridge, UK. http://dx.doi. org/10.1017/CBO9780511541957

Biermann, F., K. Abbott, S. Andresen, K. Bäckstrand, S. Bernstein, M. M. Betsill, H. Bulkeley, B. Cashore, J. Clapp, C. Folke, A. Gupta, J. Gupta, P. M. Haas, A. Jordan, N. Kanie, T. Kluvánková-Oravská, L. Lebel, D. Liverman, J. Meadowcroft, R. B. Mitchell, P. Newell, S. Oberthür, L. Olsson, P. Pattberg, R. Sánchez-Rodríguez, H. Schroeder, A. Underdal, S. Camargo Vieira, C. Vogel, O. R. Young, A. Brock, and R. Zondervan. 2012. Navigating the Anthropocene: improving earth system governance. Science 335(6074):1306-1307. http://dx.doi.org/10.1126/ science. 1217255

Binot, A., T. Blomley, L. Coad, F. Nelson, D. Roe, and C. Sandbrook. 2009. What has CBNRM achieved in Africa? The '3Es' - empowerment, economics, environment. Pages 55-94 in D. Roe, F. Nelson, and C. Sandbrook, editors. Community management of natural resources in Africa: impacts, experiences and future directions. Natural Resource Issues No. 18. International Institute for Environment and Development, London, UK.

Boele, R., H. Fabig, and D. Wheeler. 2001. Shell, Nigeria and the Ogoni. A study in unsustainable development: II. Corporate social responsibility and 'stakeholder management' versus a rights-based approach to sustainable development. Sustainable Development 9(3):121-135. http://dx.doi.org/10.1002/sd.161

Bond, I., and J. Mayers. 2010. Fair deals for watershed services: lessons from a multi-country action-learning project. Natural Resource Issues 13. International Institute for Environment and Development (IISD), London, UK.

Borrini-Feyerabend, G., M. T. Farvar, J. C. Nguinguiri, and V. A. Ndangang. 2000. Comanagement of natural resources: organising, negotiating and learning-by-doing. German Organisation for Technial Cooperation (GTZ) and International Union for Conservation of Nature (IUCN), Kasparek, Heidelberg, Germany.

Brown, K., T. Daw, R. Rosendo, M. Bunce, and N. Cherrett. 2008. Ecosystem services for poverty alleviation: marine and coastal situational analysis. Synthesis report. University of East Anglia, Norwich, UK.
Campbell, J., E. Whittingham, and P. Townsley. 2006. Responding to coastal poverty: should we be doing things differently or doing different things? Pages 274-292 in C. T. Hoanh, T. P. Tuong, J. W. Gowing, and B. Hardy, editors. Environment and livelihoods in tropical coastal zones. CABI, Wallingford, UK. http://dx.doi. org/10.1079/9781845931070.0274

Carlsson, L., and F. Berkes. 2005. Co-management: concepts and methodological implication. Journal of Environmental Management 75(1):65-76. http://dx.doi.org/10.1016/j.jenvman.2004.11.008

Cesar, H., L. Burke, and L. Pet-Soede. 2003. The economics of worldwide coral reef degradation. Cesar Environmental Economics Consulting, Arnhem, The Netherlands.

Charles, A. T. 2001. Sustainable fishery systems. Blackwell Science, Oxford, UK. http://dx.doi.org/10.1002/9780470698785

Charles, A., and L. Wilson. 2009. Human dimensions of marine protected areas. ICES Journal of Marine Science 66(1):6-15. http://dx.doi.org/10.1093/icesjms/fsn182

Chomsky, N. 1999. Profit over people. Neoliberalism and global order. Seven Stories, New York, New York, USA.

Christie, P. 2004. Marine protected areas as biological successes and social failures in southeast Asia. American Fisheries Society Symposium 42:155-164.

Chuenpagdee, R., P. Degnbol, M. Bavinck, S. Jentoft, D. Johnson, and R. Pullin. 2005. Challenges and concerns in capture fisheries and aquaculture. Pages 25-40 in J. Kooiman, S. Jentoft, R. Pullin, and M. Bavinck, editors. Fish for life: interactive governance for fisheries. Amsterdam University Press, Amsterdam, The Netherlands.

Costanza, R., R. d'Arge, R. de Groot, S. Farberk, M. Grasso, B. Hannon, K. Limburg, S. Naeem, R. V. O’Neill, J. Paruelo, R. G. Raskin, P. Suttonkk, and M. van den Belt. 1997. The value of the world's ecosystem services and natural capital. Nature 387:25360. http://dx.doi.org/10.1038/387253a0

Costenbader, J. 2011. REDD+ benefit sharing: a comparative assessment of three national policy approaches. UN-REDD Programme, Geneva, Switzerland.

Creel, L. 2003. Ripple effects: population and coastal regions. Population Reference Bureau, Washington, D.C., USA.

Crosoer, D., L. van Sittert, and S. Ponte. 2006. The integration of South African fisheries into the global economy: past, present and future. Marine Policy 30(1):18-29. http://dx.doi.org/10.1016/ j.marpol.2005.06.013

Cunguara, B., and J. Hanlon. 2012. Whose wealth is it anyway? Mozambique's outstanding economic growth with worsening rural poverty. Development and Change 43(3):623-647. http://dx. doi.org/10.1111/j.1467-7660.2012.01779.x

Daly, H. E., and J. B. Cobb. Jr. 1989. For the common good. Redirecting the economy towards community, the environment and a sustainable future. Merlin, London, UK.

de Graaf, G., F. Marttin, J. Aguilar-Manjarrez, and J. Jenness. 2003. Geographic information systems in fisheries management and planning. Food and Agriculture Organization (FAO) Fisheries Technical Paper 449. FAO, Rome, Italy. 
Dressler, D., B. Büscher, M. Schoon, D. Brockington, T. Hayes, C. A. Kull, J. McCarthy, and K. Shrestha. 2010. From hope to crisis and back again? A critical history of the global CBNRM narrative. Environmental Conservation 37(1):515. http://dx.doi. org/10.1017/S0376892910000044

Fabinyi, M. 2008. Dive tourism, fishing and marine protected areas in the Calamianes Islands, Philippines. Marine Policy 32 (6):898-904. http://dx.doi.org/10.1016/j.marpol.2008.01.004

Fabricius, C., E. Koch, H. Magome, and S.Turner. 2004. Rights, resources and rural development: community-based natural resource management in southern Africa. Earthscan, London, UK.

Fig, D. 2011. Corrosion and externalities: the socioeconomic impacts of acid mine drainage on the Witwatersrand. Pages 300329 in J. Daniel, P. Naidoo, D. Pillay, and R. Southall, editors. New South African review 2: new paths, old compromises. Wits University Press, Johannesburg, South Africa.

Food and Agriculture Organization (FAO). 2005. Increasing the contribution of small-scale fisheries to poverty alleviation and food security. Technical Guidelines for Responsible Fisheries, Vol. 10. FAO, Rome, Italy.

Frynas, J. G. 2005. The false developmental promise of corporate social responsibility: evidence from multinational oil companies. International Affairs 81(3):581-598 http://dx.doi.org/10.1111/ j.1468-2346.2005.00470.x

Gauteng Department of Agriculture and Rural Development (GDARD). 2012. Study on the reclamation and rehabilitation of mine residue areas for development purposes, phase II: strategy and implementation plan.. GRRD, Johannesburg, South Africa.

Garmendia, E., G. Gamboa, J. Franco, J. M. Garmendia, P. Liria, and M. Olazabal. 2010. Social multi-criteria evaluation as a decision support tool for integrated coastal zone management. Ocean and Coastal Management 53(7):385-403. http://dx.doi. org/10.1016/i.ocecoaman.2010.05.001

Gaventa, J. 2006. Finding the spaces for change: a power analysis. Institute for Development Studies Bulletin 37(6):23-33. http://dx. doi.org/10.1111/j.1759-5436.2006.tb00320.x

Ghee, L. T., and M. J. Valencia. 1990. Conflict over natural resources in southeast Asia and the Pacific. United Nations University Press, Singapore.

Graham, J., and S. Sol. 2009. Rethinking governance, social conflict and livelihood choices: stories from Prieto Diaz, Philippines. International Collective in Support of Fishworkers (ICSF) Digital Library of the Commons, Chennai, India.

Ha, T. T. T., H. van Dijk, and S. R. Bush, 2012. Mangrove conservation or shrimp farmer's livelihood? The devolution of forest management and benefit sharing in the Mekong Delta, Vietnam. Ocean and Coastal Management 69:185-193. http://dx. doi.org/10.1016/j.ocecoaman.2012.07.034

Hamann, R. 2003. Mining companies' role in sustainable development: the 'why' and 'how' of corporate social responsibility from a business perspective. Development Southern Africa 20(2):237-254. http://dx.doi.org/10.1080/03768350302957
Hauck, M., and M. Sowman. 2005. Coastal and fisheries comanagement in South Africa: is there an enabling legal environment? South African Journal of Environmental Law and Policy 12(1):1-21.

Hauck, M., P. Mbatha, and S. Raemaekers. 2014. Enhancing benefits to small-scale fishers along the east coast of South Africa. 2014. Pages 37-66 in R. P. Wynberg, and M. Hauck, editors. Sharing benefits from the coast: rights, resources and livelihoods. UCT Press, Cape Town, South Africa.

Hernes, H. K., S. Jentoft, and K. H. Mikalsen. 2005. Fisheries governance, social justice and participatory decision-making. Pages 103-118 in T. S. Gray, editor. Participation in fisheries governance. Springer, Dordrecht, The Netherlands. http://dx.doi. org/10.1007/1-4020-3778-3 6

Holling, C. S. 2001. Understanding the complexity of economic, ecological, and social systems. Ecosystems 4(5):390-405. http:// dx.doi.org/10.1007/s10021-001-0101-5

Jenkins, H. 2004. Corporate social responsibility and the mining industry: conflicts and constructs. Corporate Social Responsibility and Environmental Management 11(1):23-34. http://dx.doi. org/10.1002/csr.50

Jentoft, S., and R. Chuenpagdee. 2009. Fisheries and coastal governance as a wicked problem. Marine Policy 33(4):553-560. http://dx.doi.org/10.1016/j.marpol.2008.12.002

Jones, B. T. B., and M. W. Murphree. 2004. Community-based natural resource management as a conservation mechanism: lessons and directions. Pages 64-103 in B. Child, editor. Parks in transition: biodiversity, rural development and the bottom line. Earthscan, London, UK.

Kapelus, P. 2002. Mining, corporate social responsibility and the 'community.' The case of Rio Tinto, Richards Bay minerals and the Mbonambi. Journal of Business Ethics 39(3):275-296. http:// dx.doi.org/10.1023/A:1016570929359

Katsaura, O. 2010. Socio-cultural dynamics of informal diamond mining in Chiadzwa, Zimbabwe. Journal of Sustainable Development in Africa 12(6):101-121.

Kooiman, J., S. Jentoft, R. Pullin, and M. Bavinck, editors. Fish for life: interactive governance for fisheries. Amsterdam University Press, Amsterdam, The Netherlands.

Korten, D. C. 1995. When corporations rule the world. Earthscan, London, UK.

Larson, A., and J. C. Ribot. 2004. Democratic decentralization through a natural resource lens: an introduction. European Journal of Development Research 16(1):1-25. http://dx.doi. org/10.1080/09578810410001688707

Lubke, R. A., A. M. Avis, and J. B. Moll. 1996. Post-mining rehabilitation of coastal sand dunes in Zululand South Africa. Landscape and Urban Planning 34(3-4):335-345. http://dx.doi. org/10.1016/0169-2046(95)00227-8

Madihlaba, T. 2002. The fox in the henhouse. The environmental impact of mining on communities in South Africa. Pages 156 167 in D. A. McDonald, editor. Environmental Justice in South Africa. University of Cape Town Press, Cape Town, South Africa. 
Masalu, D. C. 2000. Coastal and marine resource use conflicts and sustainable development in Tanzania. Ocean and Coastal Management 43(6):475-494. http://dx.doi.org/10.1016/S0964-5691 (00)00039-9

Mbatha, P., and R. P. Wynberg. 2014. Mining and the myth of benefits in South African rural coastal communities. 2014. Pages 67-94 in R. P. Wynberg, and M. Hauck, editors. 2014. Sharing benefits from the coast: rights, resources and livelihoods. UCT Press, Cape Town, South Africa.

Merino, A., and C. Valor. 2011. The potential of corporate social responsibility to eradicate poverty: an on-going debate. Development in Practice 21(2):156-167. http://dx.doi. org/10.1080/09614524.2011.546005

Mitchell, J., and C. Ashley. 2010. Tourism and poverty reduction: pathways to prosperity. Earthscan, London, UK.

Mitchell, J., and J. Faal. 2008. The Gambian tourist value chain and prospects for pro-poor tourism. Overseas Development Institute (ODI) Working Paper 289. ODI, London, UK.

Mokorosi, P. S., and P. van der Zaag. 2007. Can local people also gain from benefit sharing in water resources development? Experiences from dam development in the Orange-Senqu river basin. Physics and Chemistry of the Earth 32(15\&\#821118):13221329. http://dx.doi.org/10.1016/j.pce.2007.07.028

Murphree, M. W. 2004. Communal approaches to natural resource management in Africa: from whence and to where? Journal of International Wildlife Law and Policy 7(3-4):203-216. http://dx.doi.org/10.1080/13880290490883250

Nelson, F. 2010. Community rights, conservation and contested land. The politics of natural resource governance in Africa. Earthscan, New York, New York, USA.

Newell, P. 2011. The elephant in the room: capitalism and global environmental change. Global Environmental Change 21(1):4-6. http://dx.doi.org/10.1016/j.gloenvcha.2010.11.011

Newton, K., I. Cote, G. Pilling, S. Jennings, and N. Dulvey. 2007. Current and future sustainability of island coral reef fisheries. Current Biology 17(7):655-658. http://dx.doi.org/10.1016/j. cub.2007.02.054

Nicholls, A., and C. Opal, 2005. Fair trade: market-driven ethical consumption. Sage, London, UK.

Nkhata, B., A. Mosimane, L. Downsborough, C. Breen, and D. Roux. 2012. A typology of benefit sharing arrangements for the governance of social-ecological systems in developing countries. Ecology and Society 17(1): 17. [online] URL: http://www. ecologyandsociety.org/vol17/iss1/art17/

Noble, B. F. 2000. Institutional criteria for co-management. Marine Policy 24(1):69-77. http://dx.doi.org/10.1016/S0308-597X (99)00014-7

Organisation for Economic Co-operation and Development (OECD). 2012. Organisation for Economic Co-operation and Development environmental outlook to 2050. The consequences of inaction. OECD Publishing, Paris, France.

O'Rourke, D., and S. Connolly. 2003. Just oil? The distribution of environmental and social impacts of oil production and consumption. Annual Review of Environment and Resources 28 (1):587-617. http://dx.doi.org/10.1146/annurev.energy.28.050302.105617

Ostrom, E. 1990. Governing the commons. The evolution of institutions for collective action. Cambridge University Press, Cambridge, UK. http://dx.doi.org/10.1017/CBO9780511807763

Pereira, M., and M. Hauck. 2014. Sharing benefits from tourism in Mozambique: pitfalls and possibilities. Pages 95-124 in R. P. Wynberg, and M. Hauck, editors. 2014. Sharing benefits from the coast: rights, resources and livelihoods. UCT Press, Cape Town.

Pinkerton, E. W. 1989. Introduction: attaining better fisheries management through co-management-prospects, problems, and propositions. Pages 3-33 in E. Pinkerton, editor. Co-operative management of local fisheries: new directions for improving management and community development. University of British Columbia Press, Vancouver, British Columbia, Canada.

Pomeroy, R. S., and R. Rivera-Guieb. 2006. Fishery comanagement: a practical handbook. CABI, Wallingford, UK. http://dx.doi.org/10.1079/9780851990880.0000

Pomeroy, R., J. Parks, R. Pollnac, T. Campson, E. Genio, C. Marlessy, E. Holle, M. Pido, A. Nissapa, S. Boromthanarat, and N. Thu Hue. 2007. Fish wars: conflict and collaboration in fisheries management in southeast Asia. Marine Policy 31(6):645656. http://dx.doi.org/10.1016/j.marpol.2007.03.012

Ramirez, M., S. Massolo, R. Frache, and J. A. Correa. 2005. Metal speciation and environmental impact on sandy beaches due to El Salvador copper mine, Chile. Marine Pollution Bulletin 50(1):6272. http://dx.doi.org/10.1016/j.marpolbul.2004.08.010

Reid, W. V., S. A. Laird, C. A. Meyer, R. Gomez, A. Sittenfeld, D. H. Janzen, M. A. Gollin, and C. Juma. 1993. Biodiversity prospecting: using genetic resources for sustainable development. World Resources Institute, Instituto Nacional de Biodiversidad, Rainforest Alliance, and African Centre for Technology Studies.

Renard, M. C. 2003. Fair trade: quality, market and conventions. Journal of Rural Studies 19(1):87-96. http://dx.doi.org/10.1016/ $\underline{\text { S0743-0167(02)00051-7 }}$

Ribot, J. C., and N. L. Peluso. 2003. A theory of access. Rural Sociology 68(2):153-181. http://dx.doi.org/10.1111/j.1549-0831.2003. tb00133.x

Rockström, J., W. Steffen, K. Noone, Å. Persson, F. S. Chapin, III, E. Lambin, T. M. Lenton, M. Scheffer, C. Folke, H. Schellnhuber, B. Nykvist, C. A. de Wit, T. Hughes, S. van der Leeuw, H. Rodhe, S. Sörlin, P. K. Snyder, R. Costanza, U. Svedin, M. Falkenmark, L. Karlberg, R. W. Corell, V. J. Fabry, J. Hansen, B. Walker, D. Liverman, K. Richardson, P. Crutzen, and J. Foley. 2009. Planetary boundaries: exploring the safe operating space for humanity. Ecology and Society 14(2): 32. [online] URL: http:// www.ecologyandsociety.org/vol14/iss2/art32/

Roe, D., F. Nelson, and C. Sandbrook, editors. 2009. Community management of natural resources in Africa: impacts, experiences and future directions. Natural Resource Issues 18. International Institute for Environment and Development (IISD), London, UK.

Ruddle, K., and F. R. Hickey, 2008. Accounting for the mismanagement of tropical nearshore fisheries. Environment, 
Development and Sustainability 10(5):565-589. http://dx.doi. org/10.1007/s10668-008-9152-5

Saarinen, J., F. Becker, M. Haretsebe, and D. Wilson, editors. 2009. Sustainable tourism in southern Africa: local communities and natural resources in transition. Channel View, Bristol, UK.

Scheyvens, R. 2002. Tourism for development: empowering communities. Pearson Education, Singapore.

Scheyvens, R. 2007. Exploring the tourism-poverty nexus. Current Issues in Tourism 10(2-3):231-254. http://dx.doi. org/10.2167/cit318.0

Schroeder, D. 2007. Environmental justice and the market: the politics of sharing wildlife revenues in Tanzania. Society and Natural Resources 21(7):583-596. http://dx.doi.org/10.1080/08941920701759544

Schroeder, D. 2008. Benefit sharing: it's time for a definition. Journal of Medical Ethics 33(4):205-209. http://dx.doi. org/10.1136/jme.2006.016790

Sibaud, P. 2012. Opening Pandora's box: the new wave of land grabbing by the extractive industries and the devastating impact on earth. The Gaia Foundation, London, UK. [online] URL: www.gaiafoundation.org/sites/default/files/documents/Pandorasboxlowres. pdf

Sommerville, M., J. P. G. Jones, M. Rahajaharison, and E. J. Milner-Gulland. 2010.

The role of fairness and benefit distribution in community-based payment for environmental services interventions: a case study from Menabe, Madagascar. Ecological Economics 69(6):12621271. http://dx.doi.org/10.1016/j.ecolecon.2009.11.005

Sowman, M., M. Hauck, L. van Sittert, and J. Sunde. 2011. Marine protected areas management in South Africa: new policies, old paradigms. Environmental Management 47(4):573583. http://dx.doi.org/10.1007/s00267-010-9499-x

Spangenberg, J. H., and J. Settele. 2010. Precisely incorrect? Monetising the value of ecosystem services. Ecological Complexity 7(3):327-337. http://dx.doi.org/10.1016/j.ecocom.2010.04.007

Spenceley, A., editor. 2008. Responsible tourism: critical issues for conservation and development. Earthscan, London, UK.

Srinivasan, U. T., S. P. Carey, E. Hallstein, P. A. T. Higgins, A. C. Kerr, L. E. Koteen, A. B. Smith, R. Watson, J. Harte, and R. B. Norgaard. 2008. The debt of nations and the distribution of ecological impacts from human activities. Proceedings of the National Academy of Sciences of the USA 105(5):1768-1773. http://dx.doi.org/10.1073/pnas.0709562104

The Economics of Ecosystems and Biodiversity (TEEB). 2010. Mainstreaming the economics of nature: a synthesis of the approach, conclusions and recommendations of TEEB. TEEB, Geneva, Switzerland.

Tumusiime, D., and P. Vedeld. 2012. False promise or false premise? Using tourism revenue sharing to promote conservation and poverty reduction in Uganda. Conservation and Society 10 (1):15-28. http://dx.doi.org/10.4103/0972-4923.92189

Turner, R. K., and B. Fisher. 2008. Environmental economics. To the rich man the spoils. Nature (451)7182:1067-1068. http://dx. doi.org/10.1038/4511067a
Twerefou, D. 2009. Mineral exploitation, environmental sustainability and sustainable development in EAC, SADC and ECOWAS regions. Work in Progress No. 79. African Trade Policy Centre, United Nations Economic Commission for Africa (UNECA), Addis Ababa, Ethiopia.

Tyler, R. M., and R. C. A. Minnitt. 2004. A review of sub-Saharan heavy mineral sand deposits: implications for new projects in southern Africa. The Journal of South African Institute of Mining and Metallurgy 104(2):89-100.

United Nations (UN). 1992. Convention on biological diversity. United Nations Environment Programme (UNEP), Geneva, Switzerland.

UN. 2010. Nagoya Protocol on access to genetic resources and the fair and equitable sharing of benefits arising from their utilization to the Convention on Biological Diversity. Secretariat of the Convention on Biological Diversity, Montreal, Quebec, Canada.

van der Duim, R., Meyer, D., Saarinen, J., and K. Zellmer, editors. 2011. New alliances for tourism, conservation and development in eastern and southern Africa. Eburon, Delft, The Netherlands.

Vivier, L. 2010. Macrobenthic community and ecotoxicological status of the Nhlabane Estuary. Dissertation. University of Zululand, Richards Bay, South Africa.

Vivier, L., and D. P. Cyrus. 1999. Dune mining and the Nhlabane Estuary, South Africa: the effect of a dredger crossing on the zoobenthic community. Marine Pollution Bulletin 39(1-12):308314. http://dx.doi.org/10.1016/S0025-326X(99)00114-9

Wegner, G., and U. Pascual. 2011. Cost-benefit analysis in the context of ecosystem services for human well-being: a multidisciplinary critique. Global Environmental Change 21 (2):492-504. http://dx.doi.org/10.1016/j.gloenvcha.2010.12.008

World Health Organization (WHO). 2005. Ecosystems and human well-being: health synthesis. Millennium ecosystem assessment. WHO, Geneva, Switzerland.

Wilson, D. C., J. Raakjaer Nielsen, and P. Degnbol, editors. 2003. The fisheries co-management experience: accomplishments, challenges and prospects. Kluwer, Dordrecht, the Netherlands. http://dx.doi.org/10.1007/978-94-017-3323-6

Wilson, M. A., R. Costanza, R. Boumans, and S. Liu. 2004. Integrated assessment and valuation of ecosystem goods and services provided by coastal systems. Pages 1-24 in J. G. Wilson, editor. The intertidal ecosystem: the value of Ireland's shores. Royal Irish Academy, Dublin, Ireland.

Wynberg, R. P., and M. Hauck, editors. 2014. Pages 143-165 in> Sharing benefits from the coast: rights, resources and livelihoods. UCT Press, Cape Town, South Africa.

Wynberg, R. P., and S. L. Laird. 2007. Bioprospecting: tracking the policy debate. Environment 49(10):20-32. http://dx.doi. org/10.3200/ENVT.49.10.20-32

Wynberg, R., D. Schroeder, S. Williams, and S. Vermeylen. 2009. Sharing benefits fairly: decision-making and governance. Pages 237-257 in R. Wynberg, R. Chennells, and D. Schroeder, editors. Indigenous peoples, consent and benefit-sharing. Lessons from the San-Hoodia Case. Springer, Berlin, Germany. http://dx.doi. org/10.1007/978-90-481-3123-5 12 
Ziegler, J. 2004. The right to food. Interim report of the Special Rapporteur of the Commission on Human Rights on the Right to Food, in accordance with General Assembly Resolution 58/186. United Nations General Assembly, New York, New York, USA. 